\title{
とびら鉦の強さ試 験
}

（垂 直 加 圧 の 場 合）

正会員 波多野一 郎* 同 ○内山鉄 男林

1. 試験の目的 鋜の性能判定の条件には, 強さ, 耐 久性，轱違いの数および正碓さ，作動の円滑などの諸要 素がある，その中でも錠の強さは防盗上の重要要件なの で現在まで約 3 年に亘って試駼を実施してきた。その一 部はすでに 38 年度大会で発表したが，今回はその後に 行った陚験について報告する。

2. 試験の方法および結果の概要四一1 亿示すよう

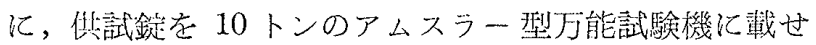

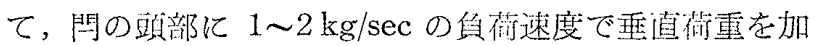
え，鋜がこわれるまでの荷重と変位睹とを測定した。

試験結果の概要は表一1 の通りである。比較のため, 38 年度大会に発表したものを表一 2 亿示した。表一1お 表-1 試 験 絓 果

\begin{tabular}{|c|c|c|}
\hline 鋜起尘 & $\begin{array}{l}\text { 試験体の種 } \\
\text { 類と個数 }\end{array}$ & $\begin{array}{c}\text { 酎力(最大荷重) } \\
(\mathrm{kg})\end{array}$ \\
\hline ピンタンブラ一鋔 $\left\{\begin{array}{lll}\text { 市 } & \text { 販 } & \text { 品 } \\
\text { 市 } & \text { 販 } & \text { 品 }\end{array}\right.$ & $\begin{array}{rr}11 & \text { 種 } \\
19 & \text { 個 } \\
1 \text { 種 } & 2 \text { 個 }\end{array}$ & $\begin{array}{r}84 \sim 1,925 \\
2,235 \sim 3,060\end{array}$ \\
\hline レバータンブラー鋜 $\left\{\begin{array}{lll}\text { 市 } & \text { 販 } & \text { 品 } \\
\text { 市 販 } & \text { 品 }\end{array}\right.$ & 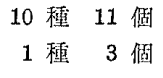 & $\begin{array}{r}80 \sim 780 \\
1,682 \sim 2,515\end{array}$ \\
\hline シリンドリカル銫 $\left\{\begin{array}{l}\text { 国限打販品未市販品 } \\
\text { 米国製品 }\end{array}\right.$ & $\begin{array}{l}5 \text { 種 } \\
1 \text { 種 } \\
6 \text { 個 } \\
6 \text { 種 }\end{array}$ & $\begin{array}{r}64 \sim 300 \\
152 \sim 763 \\
51 \sim 410\end{array}$ \\
\hline
\end{tabular}

表一2 38 年度大会発表試験結果

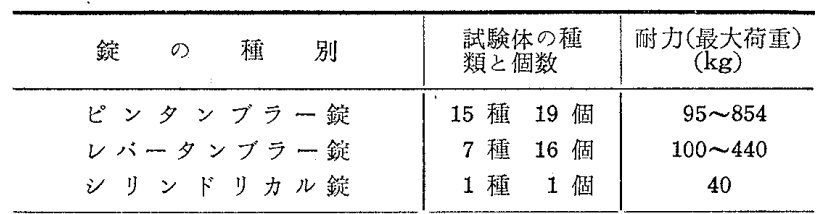

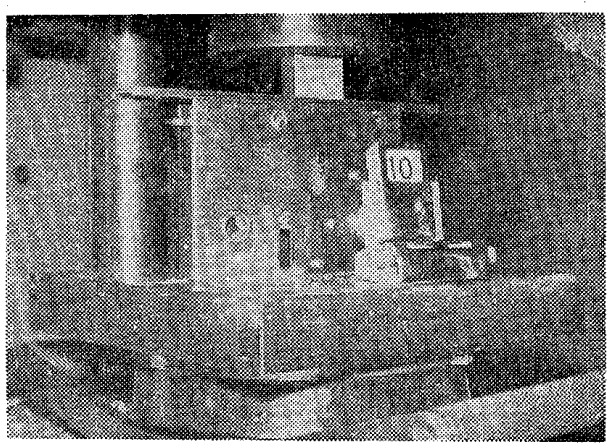

図一1 試験方法

*日本ロック研究会・千葉大学教授

** 日本ロック研究会・堀济店製造部長

よび表一2 の結果を総合すると図一2 の通りである。

測定した荷重一変位量曲線の一部を示すと，図一 3,4 , 5 の通りである。

以上の試験絬果少ら次のことが誌められる。

（1）市販の錠の強度は，全体としても，また同種類 の錠の間にも，甚だしいバラツキがある。

（2）全般的に，ピンタンブラ一䤫が最を強く，レバ 一タンブラ一鉟がてれに次ぎ，シリンドリカル銑が最も 弱い (図-2 参照)。特にシリンドリカル 錠は有効荷重 の小さいととが大きな欠点である(図一5 参照)。

（3）本試験実施以来，錠の強度は全般的に问上し た。その一例が図一3,4,5 からうかがうことができる。

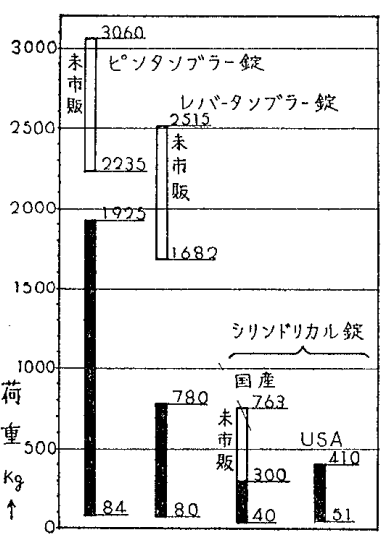

図一2 総合結果

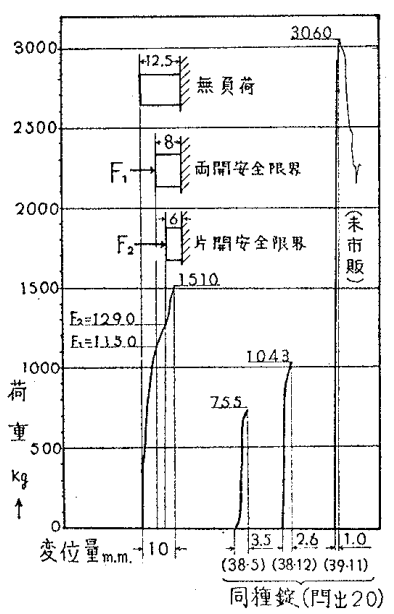

図一3 ピソタンブラー錠

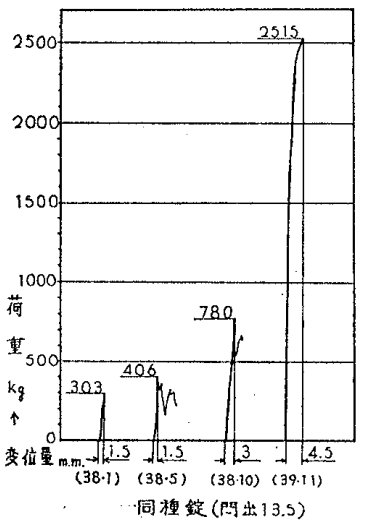

図一4 レバータンブラー錠

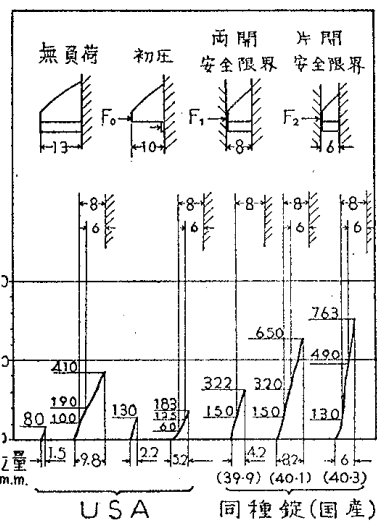

図一5 シリンドリカル鋜 